J. Dairy Sci. 95:1023-1023

doi:10.3168/jds.2012-95-2-1023

(C) American Dairy Science Association ${ }^{\circledR}, 2012$.

\title{
Erratum to "A field trial on the effect of propylene glycol on milk yield and resolution of ketosis in fresh cows diagnosed with subclinical ketosis"' (J. Dairy Sci. 94:6011-6020)
}

\section{J. A. A. McArt, D. V. Nydam, P. A. Ospina, and G. R. Oetzel}

Throughout this paper, the unit for $\beta$-hydroxybutyrate (BHBA) should be mmol/L (not $\mathrm{m} M / \mathrm{L})$.

The journal regrets the error.

\section{REFERENCES}

McArt, J. A. A., D. V. Nydam, P. A. Ospina, and G. R. Oetzel. 2011. A field trial on the effect of propylene glycol on milk yield and resolution of ketosis in fresh cows diagnosed with subclinical ketosis. J. Dairy Sci. 94(12):6011-6020. 